\title{
PERPETUITIES REFORM: AN ANALYSIS OF DEVELOPMENTS IN ENGLAND AND THE UNITED STATES
}

\author{
ROBERT J. LYNN †
}

With the enactment of the Perpetuities and Accumulations Act of $1964,{ }^{1}$ England joins Pennsylvania and those other jurisdictions having a full-blown "wait and see" version of the Rule Against Perpetuities. ${ }^{2}$ Provisions in the act for reducing age contingencies ${ }^{3}$ and splitting gifts ${ }^{4}$ abrogate the "all-or-nothing" rule of Leake $v$. Robinson ${ }^{5}$ under which many class gifts fell victim to the orthodox rule. The more common of the fantastic possibilitiesthe fertile octogenarian, ${ }^{6}$ the precocious toddler, ${ }^{7}$ and the unborn

$\dagger$ Professor of Law, Ohio State University. B.Sc. 1942, J.D. 1948, Ohio State University; J.S.D. 1952, Yale University. Member, Ohio Bar.

113 Eliz. 2, c. 55.

2 The pioneering "wait and see" statute is that of Pennsylvania enacted in 1947. PA. STAT. ANN. tit. 20, $\$ 301.4$ (1950). The language of $\$ 301.4$ is unnecessarily awkward. A simple form of "wait and see" is in substance a variation of John Chipman Gray's statement of the Rule Against Perpetuities: No interest is good unless it vests, if at all, not later than twenty-one years after some life in being at the creation of the interest. Gray, THE RULE Agarnst Perpeturtres $\$ 201$, at 191 (4th ed. 1942). New Hampshire adopted "wait and see" by judicial decision, Merchants Nat'l Bank v. Curtis, 98 N.H. 225, 97 A.2d 207 (1953), and combines it with cy pres, Edgerly v. Barker, 66 N.H. 434, 31 Atl. 900 (1891). Both Kentucky and Vermont also couple cy pres with "wait and see." Ky. REv. STAT. \$381.216 (1962); VT. STAT. ANN. tit. 27, $\$ 501$ (1959). Limited or modified "wait and see" coupled with cy pres statutes exist in Connecticut, CoNN. GEN. STAT. REv. \$\$ $45-95$ to -96 (1958) ; Maine, Me. Rev. Stat. ANn. ch. 160, \$\$27-28 (Supp. 1963); Maryland, MD. ANn. CODE art. 16, \$197A (Supp. 1964); and Massachusetts, MASs. Gen. LAws ANn. ch. $184 \mathrm{~A}, \S \S 1-2(1955)$. The Washington "wait and see" statute is applicable to interests created by trusts only. WASH. REv. CODE ANN. $\$ 111.98 .010-.030$ (1963). The Western Australian statute is generally comparable to the newly enacted English legislation. Law Reform (Property, Perpetuities, and Succession) Act, 1962, 11 Eliz. 2, No. 83 (W. Austl.).

3 Perpetuities and Accumulations Act, 1964, 13 Eliz. 2, c. 55, \&4. Age contingencies are reduced only to the extent required to validate the gift, not necessarily to twenty-one.

4 Perpetuities and Accumulations Act, 1964, 13 Eliz. 2, c. 55, §4(4). Members of the class whose inclusion would make the gift void for remoteness are excluded from the class.

52 Mer. 363, 35 Eng. Rep. 979 (Ch. 1817).

- Suppose a devise to $A$ for life, then to $A^{\prime}$ 's children for their lives, remainder to the grandchildren of $A$. $A$ is a woman eighty years of age at the execution of the will. If "children" is construed to mean "children of $A$ whenever born" and "grandchildren" is construed to mean "grandchildren of $A$ whenever and to whomever born," the gift to the grandchildren is bad under the orthodox rule because the ultimate number of grandchildren sharing in the gift might not be known until the death of a person unborn at the testator's death, namely an afterborn child of $A$. Leach calls this the "fertile octogenarian" case. See 6 AMERICAN LAW OF PROPERTY \$24.22 (Casner ed. 1952).

7 Suppose a devise to $A$ for life, remainder to such of the grandchildren of $A$ living at my (the testator's) death or born within five years thereafter as attain 
widow ${ }^{8}$-receive special attention. ${ }^{9}$ Powers of appointment are defined for perpetuities purposes. ${ }^{10}$ Specification of a period in gross not to exceed eighty years as the perpetuities period is made permissible. ${ }^{11}$ In short the orthodox rule in England now becomes the old Rule Against Perpetuities. ${ }^{12}$

Does enactment of the new statute make the old learning obsolete-the differentiation of present and future interests, the arrangement of interests within the future interests hierarchy, and the classification of future interests as vested or contingent? May an American lawyer freed to some extent from the orthodox rule by the adoption of a "wait and see" or a cy pres ${ }^{13}$ version reasonably feel condescending toward those of his brethren at the bar seemingly doomed to continue for some time-perhaps even indefinitely - to practice under the orthodox rule? ${ }^{14}$

Even a quick perusal of the act bears out the answer already given to the first of these questions by a current commentator on the English statute: "The Act works within the framework of the old rule

twenty-one. If "grandchildren" is construed to mean "grandchildren of $A$ whose parent or parents (a child or children of $A$ ) are born at any time," the gift to the grandchildren is bad under the orthodox rule. $A$ might have another child after the testator's death and such afterborn child might marry and have a child within five years after the testator's death. The unborn child of $A$ 's unborn child might attain the prescribed age and qualify to share in the remainder. Therefore, the ultimate number of grandchildren sharing in the gift might not be known until twenty-one years after the birth of a child to the afterborn child of $A$. Leach calls this the "precocious toddler" case. Ibid.

${ }^{8}$ Suppose a devise to $A$ for life, then to $A$ 's widow for life, remainder to such of the children of $A$ as survive the survivor of $A$ and $A$ 's widow. If "children" is construed to mean "children of $A$ whenever born" and "widow" is construed to mean "that wife of $A$, whenever born, who survives $A$," the gift to the children is bad under the orthodox rule because identification of the children who qualify to share in the gift might be deferred until the death of a person unborn at the testator's death-the "unborn widow." Id. \$24.21.

9 Perpetuities and Accumulations Act, 1964, 13 Eliz. 2, c. 55, $\S 2,5$. The fertile octogenarian and precocious toddler problems are handled by rebuttable presumptions with respect to the ability to conceive. Section 5 eliminates the unborn widow trap by providing that if the death of the survivor of $A$ and $A$ 's widow, note 8 supra, has not occurred when the perpetuities period has run, and the gift to the children would otherwise be bad, identification of the children who share in the gift shall be fixed at the end of the perpetuities period. For an approach to the unborn widow problem under American "wait and see" cy pres versions of the rule see Lynn, A Practical Guide to the Rule Against Perpetuities, 1964 DuKE L.J. 207, 231 n.87.

10 Perpetuities and Accumulations Act, 1964, 13 Eliz. 2, c. 55, \$7.

11 Perpetuities and Accumulations Act, 1964, 13 Eliz. 2, c. 55, §1.

12 There may be some confusion in this connection. Before the passage of the new act, it was conventional to call the rule of Whitby v. Mitchell, $42 \mathrm{Ch}$. D. 494 (1889), aff'd, 44 Ch. D. 85 (1890), the old Rule Against Perpetuities. The rule of Whitby, namely, that a limitation to the issue of the unborn taker of a life interest is void, is not a part of the law of the United States. SIMES \& SMITE, Future INTERESTS $\$ \S 1218-19$ (2d ed. 1956) [hereinafter cited as SimES \& SMrTH]. It was abolished in England by the Law of Property Act, 1925, 15 \& 16 Geo. 5, c. 20, 1161 (1). ${ }^{13} \mathrm{~A}$ cy pres version of the rule was adopted in California in 1963. CAL. CIV. Code $\$ 715.5$ (Supp. 1964), Comment, 16 STAN. L. Rev. 177 (1963).

14 The orthodox rule exists in about three-fourths of the jurisdictions in the United States. 6 AMERICAN LAw OF ProperTy \$25.1, at 167 (Casner ed. 1952). 
"15 The old familiar words-c"vest," 18 "class," 17 "interest" 18_are comforting by their presence. In England, as in the United States, applying the "wait and see" version of the rule presupposes the traditional approach to solution of a perpetuities problem: analyzing the limitations in the dispositive instrument as of the time of their creation to determine whether any gifts are future, isolating those future gifts which are remainders and executory interests, characterizing the remainders and executory interests as vested or contingent, and determining whether any contingent interest is bad ab initio.

Evaluating the merits of the "wait and see" rule is more difficult. "Wait and see" unquestionably attracts us because it appears to defer settling a perpetuities question, and all of us are prone to put off a troublesome matter until another day. But postponing the perpetuities question is not inevitable, even under "wait and see." Suppose a devise to $A$ for life, remainder to that child of $A$ who first attains twenty-five. $A$ is a bachelor at the testator's death. The contingent remainder is not necessarily bad ab initio under "wait and see." A child may be born to $A$ and attain the prescribed age within the perpetuities period, namely, $A$ 's lifetime and twenty-one years. If so, the contingent remainder vests within the perpetuities period and is good under "wait and see." But suppose $A$ is incapable of conceiving a child at and after the testator's death. Under the Rule Against Perpetuities in orthodox form, the invalidity of the contingent remainder turns on the fantastic possibility that $A$ might have a child who might attain twenty-five at a remote time. Under "wait and see" the inability of $A$ to conceive is a fact (in the language of the Pennsylvania statute, an "actual event" ${ }^{19}$ ) that justifies a declaration of invalidity at the testator's death. To refuse to declare the contingent remainder invalid under "wait and see" because the perpetuities period has not run is absurd unless there is a persuasive reason for deferring the determination of invalidity.

Here the English act is superior to its American counterparts, for it supplies help in establishing facts. Section 2 of the act creates a rebuttable presumption that a male under the age of fourteen cannot conceive and that a female under the age of twelve or over the age (1964).

15 Battersby, The Perpetuities and Accumulations. Act, 1964, 108 Sol. J. 627

16 Perpetuities and Accumulations Act, 1964, 13 Eliz. 2, c. 55, § 3(1).

17 Perpetuities and Accumulations Act, 1964, 13 Eliz. 2, c. 55, §4(4).

18 Perpetuities and Accumulations Act, 1964, 13 Eliz. 2, c. 55, $\$ 6$.

19 Pa. Stat. AnN. tit. 20, §301.4 (1950). 
of fifty-five cannot conceive. ${ }^{20}$ With respect to adoption, legitimation, or "other means" of having a child, these presumptions are conclusive. ${ }^{21}$ Generally speaking, in the United States one can only speculate about the perpetuities effects of adoption or the preservation of sperm. ${ }^{22}$ American adoption statutes tend to take the adopted child from the family into which he was born and put him into the family of his adopting parent or parents, ${ }^{23}$ but the language of the statutes tends to be general, not specific. It may be hazarded that for perpetuities purposes the possible or the actual adoption of a child after the death of the testator should be disregarded if the inclusion of such adopted child jeopardizes a gift. But it must be conceded that the reasons for this view lie in logic rather than statute or case.

Even if the perpetuities question cannot be deferred in every case under "wait and see," those supporting the newer version of the Rule Against Perpetuities can assert effectively that the question may be deferred in many cases, and indeed that is so. ${ }^{24}$ Beyond that, and more to the point, a limitation unquestionably bad under the orthodox rule may be good under "wait and see." A devise to $A$ for life, remainder to that child of $A$ who first attains twenty-five is unquestionably bad under the old rule if $A$ is a bachelor at the testator's death. It is bad irrespective of when the perpetuities question is raised. It is bad irrespective of the fact that a child of $A$ does attain twenty-five within $A$ 's lifetime and twenty-one years. It is undeniably true that more contingent gifts will be saved under "wait and see" than under the orthodox rule.

\section{Modernization of the Rule}

It does not follow, however, that those living with the orthodox rule need apologize for its rigors. Evidence accumulates that the orthodox rule is being modernized. Two recent cases from California and Texas are demonstrative. In Wong v. Di Grazia, ${ }^{25}$ the plaintiff and

20 Comparable legislation has been suggested in the United States: "(a) if a person is a male of the age of [55].. or over, or a female of the age of [50] - . or over, at the commencement of the perpetuities period, he or she shall be conclusively presumed to be incapable of procreating or bearing a child or children ..." Section of Real Property, Probate, and Trust Law, abA, Perpetuity Legislation HandBook 14 (2d ed. 1962).

21 Perpetuities and Accumulations Act, 1964, 13 Eliz. 2, c. 55, §2(4).

22 See generally Leach, Perpetuities in the Atomic Age: The Sperm Bank and the Fertile Decedent, 48 A.B.A.J. 942 (1962); Leach, Perpetuities: New Hampshire Defertilizes the Octogenarians, 77 HaRv. L. Rev. 279 (1963).

23 Harper \& Skolnick, Problems of the Family 214-15 (rev. ed. 1962).

24 Lynn, A Practical Guide to the Rule Against Perpetuities, 1964 Duke L.J. 207, 219-23, 228-31, 237-39, 242-45.

2560 Cal. 2d 525, 386 P.2d 817, 35 Cal. Rptr. 241 (1963). 
defendant signed a lease which was to commence upon the completion of a building by the lessor. Ultimately the lessee questioned the validity of the lease under the Rule Against Perpetuities, which, of course, evaluates a contingent future interest through a possibilities test, not by a probabilities or actualities criterion. If the vesting of a contingent future interest is conditioned on an event that might occur, if it occurs at all, at a remote time, the interest is bad under the orthodox rule. The California District Court of Appeal did declare the lease invalid on the ground that the lessee's interest might vest remotely because the building might not be completed within the period in gross of twenty-one years. ${ }^{28}$ The California Supreme Court reversed, refusing "to interpret the rule [against perpetuities] so as to create commercial anomalies. . . . Our task is not to block the business pathway but to clear it, defining it by guideposts that are reasonably to be expected." 27 The court found that under contract law the building would have to be finished within a reasonable time. In this case a reasonable time was less than twenty-one years.

The same reasonableness is evident in Mattern $v$. Herzog. ${ }^{28}$ There the testatrix devised real estate to nine of her children, the interests of eight being subject to an option to purchase in the ninth. In an action to construe the will and to quiet title, five of the nine children argued that the option violated the Rule Against Perpetuities because it might be exercised, if at all, at a remote time. But the Texas Supreme Court, noting that the holder of the option was entitled under the will to deduct from the purchase price such sums as he had contributed toward the support of his parents, held that the option was good because exercisable only "during a reasonable period of time bearing some relationship with the time required to administer and finally settle the . . . estate [of the testatrix]." 29

Of course there are recent cases decided under the orthodox rule that are wrong in result. In Burton v. Hicks, ${ }^{30}$ the testatrix directed that money and bonds be held in trust by her executor "for twentyfive . . . years and then [be] divided one-third to Norris . . onethird to James . . . and one-third to . . . Dorothy . . . in case she is living, if not, to be divided equally between . . . Norris . . . and James . . . Before the twenty-five year period had run, Dorothy brought an action against the administrator, with the will annexed,

28 Wong v. Di Grazia, 29 Cal. Rptr. 86 (Dist. Ct. App. 1963).

2760 Cal. 2 d at $525,533-34,386$ P.2d at $817,823$.

28367 S.W.2d 312 (Tex. 1963).

29 Id. at 318.

30220 Ga. 29, 136 S.E.2d 759 (1964). 
seeking immediate distribution of her one-third of the fund. Dorothy alleged that she, Norris, and James were all sui juris and had no intemperate, wasteful, or profligate habits. Dorothy further alleged that the trust violated the Rule Against Perpetuities and was "fully executed." The trial court sustained a general demurrer to the petition, and Dorothy appealed. The Georgia Supreme Court affirmed, holding the trust void because its duration violated the Rule Against Perpetuities. The court quoted with approval from an earlier Georgia case, Fuller $v$. Fuller: "There is only one specification of the time for the trust to continue which is 25 years. And this is unrelated to the life of any person therein referred to." 32 The trust being void in its entirety, the fund passed by intestacy.

The Rule Against Perpetuities is a rule against remoteness of vesting. ${ }^{33}$ It does not directly limit the duration of trusts. ${ }^{34}$ The testatrix in Burton attempted to create three contingent interests with respect to one-third of the fund: that one-third went to Dorothy if she survived to the time of distribution, and if she did not, it went to Norris and James. Not one of these interests was so created that it might vest, if at all, at a remote time. Within her own lifetime Dorothy would survive, or not survive, the running of the twenty-five year term of the trust. Therefore, her life was a "measuring life" for the purpose of demonstrating the validity of the contingent future interests under the rule.

31217 Ga. 316, 122 S.E.2d 234 (1961).

32 Id. at $323-24,122$ S.E.2d at 238 . In turning to Fuller as a precedent for invalidating a trust that might last longer than the perpetuities period, the Georgia court overlooked dicta respecting trust duration in Lanier v. Lanier, $218 \mathrm{Ga}$. 137, 126 S.E.2d 776 (1962): "The correct rule is . . . . . . beneficial interests under or after a trust, which are vested immediately or will necessarily vest, if ever, within the period prescribed by the rule [against perpetuities], are good, even though the trust may continue beyond such time . . ." Id. at 143, 126 S.E.2d at 780 . (Emphasis added.)

33 Gray, The Rule Against Perpetuities 3-4 (4th ed. 1942). Powell disagrees: "By [Gray's formulation of the rule] . . the profession has been misled to believe that the rule now concerns, and in the past did concern, only remoteness of vesting." Powell, Nutshells and Perpetuities, 7 U. CHr. I. REv. 489, 492 (1940). Powell has reasserted his position with respect to the rule in his treatise. 5 PowELL, ReAL Property IT 762, 767A (1962) [hereinafter cited as PowerL]. He prefers the description of the rule in the RESTATEMENT, PROPERTY $\$ 370$, comment $i$, at 2150 (1944): "[T] The rule against perpetuities promotes alienability by destroying future interests which interfere therewith either by eliminating the power of alienation for too long a time or by lessening the probability of alienation for too long a time ...." Nevertheless, Gray's conception of the rule is generally accepted today. 6 AMrerican Law of Property \$24.3 (Casner ed. 1952); Smins \& Smrth \$1222. Certainly courts in recent cases zerite about the rule as a rule against remoteness. E.g.j Jones Estate, 29 Pa. D. \& C.2d 437, 444 (Orphans' Ct. Allegheny County 1962), aff'd, 410 Pa. 380, 190 A.2d 120 (1963).

346 American Law of Property \$24.67 (Casner ed. 1952); 5 Powell $\llbracket 772$ (1) ; 1 Scotr, Trusts $\$ 62.10$, at $543-44$ (2d ed. 1956) ; Simes \& SMITH $\$ 1391$, at 240 . A provision in a private trust instrument that makes it indestructible beyond the period of the common-law Rule Against Perpetuities is void. Id. \$1391, at 241. 
Burton reaches a result that is almost indefensible. The Georgia court assumed that if the term of the trust was void, the interests created by the will were void also. There is no compelling reason to invalidate an equitable interest because an illegal restraint has been put on possession. The court should have declared the twenty-five year trust term void ${ }^{35}$ and should have recast the gift to Dorothy to read: ". . . one-third to . . . Dorothy, in case she is living twenty-five years hence, and if she dies before the twenty-five year period has elapsed, then to Norris . . . and James . . . ."

Wong, Mattern, and Burton were all decided under the rule in orthodox form. Both Wong and Mattern attained sensible solutions of perpetuities problems despite dissenting views. ${ }^{36}$ Decision was reached in Burton without dissent. Burton is typical of the cases which have brought the Rule Against Perpetuities into disrepute. Without an analysis of the limitations in the dispositive instrument to determine whether or not a perpetuities question is properly raised, ${ }^{37}$ the case is treated as one where the perpetuities problem is present. That door to invalidating a disposition having been opened so carelessly, no effort is required to let the rule do its dirty work. And several more disappointed beneficiaries and their discredited counsel can point to the rule as the cause of their grief.

There will be more cases like Burton, for irrespective of the form which the rule takes, there are likely to be cases applying it badly. There is no reason to think that from the great mass of litigation reaching the courts, perpetuities cases will be singled out for special attention. There are, nevertheless, reasons for viewing this backwater of the law with less of the distaste customarily accorded it.

First, there have been sweeping reforms of the orthodox rule either by legislation or judicial decision. Reformation of the rule has followed three patterns:

(1) A judicial re-ordering of interests to comply with the requirements of the rule has been made mandatory in some situations where the rule in orthodox form is violated. Cy pres reformation of this kind applies the rule for the construction of an instrument in equity, by which the intention of the donor is carried out as nearly as possible when it is impossible or illegal to give it literal effect. California

35 See $i d . \S 1391$.

36 Wong v. Di Grazia, 60 Cal. 2d 525, 544, 386 P.2d 817, 830, 35 Cal. Rptr. 241, 254 (1963) (dissenting opinion); Mattern v. Herzog, 367 S.W.2d 312, 320 (Tex. 1963) (dissenting opinion).

37 In First Portland Nat'l Bank v. Rodrique, 157 Me. 277, 172 A.2d 107 (1961), the Maine Supreme Court found it unnecessary to classify interests before resolving the perpetuities question. Id. at $296,172 \mathrm{~A} .2 \mathrm{~d}$ at 117 . 
adopted a full scale cy pres version of the Rule Against Perpetuities in $1963 .^{38}$

(2) The classic possibilities test for the validity of contingent future interests under the rule has been abandoned, and an actualities or "wait and see" test has been adopted. Pennsylvania adopted a full scale "wait and see" version of the Rule Against Perpetuities in 1947.39

(3) The classic possibilities test for the validity of contingent future interests under the rule has been abandoned, and a version of the rule coupling "wait and see" with cy pres has been adopted. New Hampshire developed such a rule by judicial decision. ${ }^{40}$

Second, aspects of the orthodox rule which have brought it into disrepute have been affected by the adoption of statutes designed to correct such deficiencies. In the United States possibilities of reverter and rights of entry for condition broken are exempt from the rule. ${ }^{41}$ Statutes now exist in some jurisdictions which both complement and supersede the Rule Against Perpetuities by conditioning the continued existence of such interests either on the occurrence of the contingency within a specified length of time, such as thirty years, ${ }^{42}$ or on the timely registration of a "preserving notice." ${ }^{43}$ Statutes eliminating

38 CAL. Crv. Code $\$ 715.5$ (Supp. 1964).

39 Pa. Stat. Ann. tit. 20, §§ 301.4-.5 (1950).

40 See Merchants Nat'l Bank v. Curtis, 98 N.H. 225, 97 A.2d 207 (1953);

Edgerly v. Barker, 66 N.H. 434, 31 Atl. 900 (1891).

41 See 6 AMrerican LaW of Property $\$ 24.17$ (Casner ed. 1952) ; 5 Powell $\llbracket 769$; Srmes \& SMith $\$ \$ 1238-39$.

42 E.g., Mass. ANn. Laws ch. 184A, § 3 (Supp. 1963) :

A fee simple determinable in land or a fee simple in land subject to a right of entry for condition broken shall become a fee simple absolute if the specified contingency does not occur within thirty years from the date when such fee simple determinable or such fee simple subject to a right of entry becomes possessory. If such contingency occurs within said thirty years the succeeding interest, which may be an interest in a person other than the person creating the interest or his heirs, shall become possessory or the right of entry exercisable notwithstanding the rule against perpetuities.

43 E.g., Orro Rev. Code ANn. $\$ \$ 5301.49$, .51 (Page Supp. 1964) :

Such record marketable title shall be subject to:

.... All interests and defects which are inherent in the muniments of which such chain of record title is formed; . . . provided that . . . possibilities of reverter, and rights of entry or powers of termination for breach of condition subsequent, which interests are inherent in the muniments of which such chain of record title is formed and which have existed for forty years or more, shall be preserved and kept effective only in the manner [hereinafter] provided. . . .

$\cdot \cdot \cdot$

. . . Any person claiming an interest in land may preserve and keep effective such interest by filing for record during the forty-year period immediately following the effective date of the root of title of the person whose record title would otherwise be marketable, a notice in writing . . . setting forth the nature of the claim .... 
the "administration contingency" 44 and "unborn widow" 45 constructions have been enacted here and there.

Third, problems related to perpetuities problems, but clearly separable from them, have been singled out for special treatment by legislation. The Rule Against Perpetuities does not directly limit the duration of trusts, but problems of trust duration are frequently confused with problems of remoteness of vesting. Legislation designed to meet the problem of trust duration has been enacted recently in California. ${ }^{46}$

Fourth, the orthodox rule has been modernized by judges. Updating the rule has taken a number of forms:

(1) The hierarchy of future interests is being simplified. For perpetuities purposes, courts tend to treat contingent remainders, con-

44 E.g., Ill. Ann. Stat. ch. 30, §153(a) (Supp. 1964) :

The vesting of any limitation of property, whether created in the exercise of a power of appointment or in any other manner, shall not be regarded as deferred for purposes of the rule against perpetuities merely because the limitation is made to the estate of a person or to a personal representative, or to a trustee under a will, or to take effect on the probate of a will ... . 45 E.g., CaL. Crv. Code \$ 715.7 (Supp. 1964):

In determining the validity of a future interest in real or personal property [under the Rule Against Perpetuities] . . . an individual described as the spouse of a person in being at the commencement of a perpetuities period shall be deemed a "life in being" at such time whether or not the individual so described was then in being.

This statute was enacted as a part of the reform legislation of 1963.

46 The California statute is as follows:

A trust is not invalid, either in whole or in part, merely because the duration of the trust may exceed the time within which future interests in property must vest under [the Rule Against Perpetuities] . . . if the interest of all the beneficiaries must vest, if at all, within such time.

If a trust is not limited in duration to the time within which future interests in property must vest under [the Rule Against Perpetuities] . . a provision, express or implied, in the instrument creating the trust that the trust may not be terminated is ineffective insofar as it purports to be applicable beyond such time. A provision, express or implied, in an instrument creating an inter vivos trust that the trust may not be terminated shall not prevent termination by the joint action of all of the creators of the trust and all of the beneficiaries thereunder if all concerned are competent and if the beneficiaries are all of the age of majority.

Whenever a trust has existed longer than the time within which future interests in property must vest under [the Rule Against Perpetuities] . . .

(1) It shall be terminated upon the request of a majority of the beneficiaries (2) It may be terminated by a court of competent jurisdiction upon the petition of the Attorney General or of any person who would be affected thereby if the court finds that such termination would be in the public interest or in the best interest of a majority of the persons who would be affected thereby.

Cal. Crv. Cone $\$ 771$ (Supp. 1964). (Emphasis added.) The California rule is comparable to that stated by Scott:

Where there is a trust for several beneficiaries which may continue beyond the period of the rule against perpetuities, it would seem that the provision in the trust instrument that the trust should not terminate, even though all of the beneficiaries should desire to terminate it, is invalid, at least to the extent to which it is intended to be applicable beyond the period of the rule against perpetuities.

1 ScotT, TRUSTs $\$ 62.10$ (2) (b) (2d ed. 1956). (Emphasis added.) 
tingent executory interests, possibilities of reverter, rights of entry for condition broken, and possibilities of resulting trust as equivalents. ${ }^{47}$

(2) Features of the rule that are too technical for easy comprehension are being sloughed off. It can no longer be said with assurance that to be good under the rule a contingent executory interest must be so created that it will become possessory, if it takes effect at all, within the perpetuities period. ${ }^{48}$ Applications of the rule that are unusually harsh are being rejected. The class gift doctrine of Leake v. Robinson ${ }^{49}$ is a recent victim of this kind of reformation of the orthodox rule. ${ }^{50}$

(3) Substance is being stressed, rather than form. A single piece of paper now does tasks once thought achievable only through two. ${ }^{51}$ Where appropriate, the nonexercise of a power of appointment is treated as the equivalent of an exercise of the power. ${ }^{52}$

47 Lynn \& Van Doren, Applying the Rule Against Perpetuities to Remainders and Executory Interests: Orthodox Doctrine and Modern Cases, 27 U. CHr. L. REv. 436, 444 (1960) ; Lynn \& Ramser, Applying the Rule Against Perpetuities to Functional Equivalents: Copps Chapel and the Woburn Church Revisited, 43 Iowa L. REv. 36, 40 (1957).

48 See Lynn, A Practical Guide to the Rule Against Perpetuities, 1964 Duke L.J. 207,245 n.130.

492 Mer. 363, 35 Eng. Rep. 979 (Ch. 1817).

50 Lynn \& Carpenter, Applying the Rule Against Perpetuities to Class Gifts: the Influence of Leach, 43 TEXAS L. REv. 37 (1964).

51 In Brown v. Terra Bella Irr. Dist., 51 Cal. 2d 33, 330 P.2d 775 (1958), land was granted to the district with a "reservation" of all gas, oil, and minerals underlying the land. The reservation was to continue for twenty-five years from delivery of the deed and as long thereafter as profitable. Subject to the "reservation," the deed granted all of the land "together with . . the reversion and . . . remainder" to the district. Id. at 35, 330 P.2d at 776. The California Supreme Court held that even if the gift over to the district following the reserved fee simple determinable were void under the rule, an "interest in the reversion" passed to the district under the deed. Id. at 37, 330 P.2d at 777.

Brozem v. Terra Bella Irr. Dist. involved an inter vivos transfer. Its counterpart in the testamentary field is Brown v. Independent Baptist Church, 325 Mass. 645, 91 N.E.2d 922 (1950). There the testatrix in 1849 devised land to a church "so long as they shall maintain and promulgate their present religious belief and faith and shall continue as a Church," then to ten named persons who were also the residuary devisees. Id. at 645, 108 N.E.2d at 923. In 1939 the church ceased to exist. In a suit to determine whether the property passed to the successors in interest of the heirs at law of the testatrix or to the successors in interest of the residuary devisees, the Massachusetts Supreme Judicial Court held that the gift over was void under the Rule Against Perpetuities. The possibility of reverter passed to the ten named persons under the residuary clause.

52 In Sears v. Coolidge, 329 Mass. 340, 108 N.E.2d 563 (1952), the settlor created an inter vivos trust in 1913, reserving to himself a power to alter or amend the trust, except that he could not vest principal or income in himself. The settlor was then 81 years of age, a widower with two living children aged 59 and 55 , both daughters. 
(4) The purpose of the rule is being re-examined, and the rule is being applied sensibly rather than remorselessiy. In this respect both Wong $^{53}$ and Mattcrn ${ }^{54}$ are representative of modern perpetuities decisions.

The reascns for judicial reformulation of the Rule Against Perpetuities are in part identifiable, ${ }^{55}$ even though it is difficult to assess the impact of each of them on the modern rule. Both ignorance of and an indifference to the rule undeniably play a part, and their not inconsiderable role in the reformation process can be documented. ${ }^{56}$ But an emerging factor in the phenomenon is the reform movement itself. It is doubtful that in the United States the rule ever existed in the classic form stated by Gray, but that matter aside, the rule in orthodox form is now much less stringent in its requirements than formerly. Judicial reformation of the orthodox rule both antedated and paralleled the press for legislative intervention. ${ }^{57}$ Legislative intervention has simply accelerated a process already underway. Here those required to work within the permissible limits of the orthodox rule have received an unexpected boon.

The accelerating process of reform can be seen at work in such recent perpetuities class gift cases as Carter v. Berry, ${ }^{58}$ In re Foster's

Principal was distributable to his then living issue on "the attainment of fifty years by the youngest surviving grandchild of [the settlor] ... who shall be living at [the settlor's] . . . death .... Id. at 342, 108 N.E.2d at 565 . The settlor died in 1920 without having exercised the power reserved. The youngest grandchild of the settlor attained 50 in 1951. No grandchild was born after the creation of the trust. The Massachusetts Supreme Judicial Court held that the validity of the gift of principal was to be determined on the basis of facts existing at the settlor's death, the nonexercise of the reserved power to alter or amend being treated as the equivalent of the exercise of a general testamentary or a special power, and the gift in default of the exercise of the reserved power being treated as the equivalent of an appointment under a general testamentary or a special power.

53 Wong v. Di Grazia, 60 Cal. 2d 525, 386 P.2d 817, 35 Cal. Rptr. 241 (1963).

54 Mattern v. Herzog, 367 S.W.2d 312 (Tex. 1963).

55 Lynn \& Carpenter, supra note 50, at 37.

56 Lynn \& Van Doren, supra note 47, at 445-49; Lynn \& Ramser, supra note 47, at $45-47$.

67 Lynn, Reforming the Common Law Rule Against Perpetuities, 28 U. CHr. L. REv. 488 (1961).

58243 Miss. 321, 136 So. 2d 871, 140 So. 2d 843 (1962). In Carter the testator arguably conditioned a gift of principal to his grandchildren on their attaining the age of twenty-five. Because the class might include grandchildren born after the testator's death, the testator's daughters contended that the gift to the grandchildren was void in its entirety under the Rule Against Perpetuities. The Mississippi Supreme Court doubted that the gift was conditioned on attaining the age of twenty-five, but the court asserted that even if it were it would save it by reducing the age contingency from twenty-five to twenty-one to meet the requirements of the rule. Id. at 369-78, 140 So. $2 d$ at $851-56$. For a complete discussion of the case, see Lynn \& Carpenter, supra note 50 , at 50-54. 
Estate, ${ }^{59}$ and Lanier $v$. Lanier, ${ }^{60}$ where limitations which would have been void under the rule if remorselessly applied were saved from destruction. It can be seen at work in the related field of accumulations. A provision directing an accumulation of income that might endure beyond the perpetuities period is void under the common-law Rule Against Accumulations, subject to one exception: there is no re-

59190 Kan. 498, 376 P.2d 784 (1962). In this case the Kansas Supreme Court precluded a violation of the Rule Against Perpetuities by excision. The testatrix disposed of her residuary estate as follows:

[A]11 the rest, residue and remainder of the Trust Estate shall be distributed at the time the youngest child of the body, and not by adoption, of my daughte: Miriam . . . reaches the age of twenty-three (23) years, or at the death of my said daughter, Miriam . . whichever event occurs the later, in the following manner and in the following shares, to wit:

a. To the children of the body, and not by adoption, of my said daughter, equally share and share alike.

b. In the event any of the children of the body, and not by adoption of my said daughter . . . die before any distribution date of said Trust, his or her share shall descend and be distributed to his or her children, and if no children, then to the surviving children of the body of my said datghter . . equally share and share alike.

Id. at 500-01, 376 P.2d at 786-87. (Emphasis added.)

The daughter and sole heir of the testatrix contended in a construction proseeding that the gifts of principal violated the Rule Against Perpetuities. The supreme court agreed, and excised the italicized language from the instrument. The court $\mathrm{m}$ 'ght have found the gifts to the children of Miriam in clause "a" vested, subject to o jen to permit after-born children to share, and subject to divestment by $g$ fts $o r$ in clause " $b$ " to: (1) a child or children of a child of Miriam who failed to sur : to the time of distribution of principal; and (2) a child or children of Miriam who survived to the time of distribution, predeceased by a child of Miriam who died wi.l'sout a child or children surviving him.

The gifts over were upon alternative contingencies, both of which were e" sss: One, Miriam dying survived by a child or children, including a child or children born after the testatrix's death, the youngest of such children thereafter attaining tweitythree; the other, Miriam dying after the youngest of her children, including a child or children born after the testatrix's death, attains twenty-three. Although the former contingency might occur remotely, the latter must occrr, if at all, w thin Miriam's lifetime. If the latter contingency occurs, the gifts over are good under the rule. If the former contingency occurs, some gifts over are good under the lle, and some gifts over are bad under the rule. For example, the g.ft over to grandchildren of Miriam whose parent (a child of Miriann) was alive at the testatriv's death is arguably good under the rule because it is saved by the rule of Catt'in v. Brown, 11 Hare 372, 68 Eng. Rep. 1319 (Ch. 1853). The number of children of Miriam will be known within Miriam's lifetime, a life in being at the testatrix's death. Therefore, the ultimate number of shares of principal is fixed within the perpetuities period. A child of Miriam alive at the testatrix's death will survive to the time of distribution, or not, within his own lifetime. If he does not survive to the time of distribution, the share of principal he represents passes to such of his children as survive him, persons identifiable within the perpetuities period. This analysis assumes that there is no requirement that such grandchildren of Miriam survive to the time of distribution.

$60218 \mathrm{Ga} .137,126$ S.E.2d 776 (1962). In Lanier the testator probably created a vested equitable estate in the children of his son, Thomas, alive at the testator's death, subject to a discretionary power, and subject to executory interests in, among others, unborn children of Thomas. But the Georgia Supreme Court discussed the gift to the grandchildren of the testator as if it were conditioned on survivorship to the time of distribution-a time that might be remote under the Rule Against Perpetuities if the "unborn widow" construction were adopted. Ultimately the court saved the gift to the grandchildren by treating the gift as immediate, rather than future, and using the principle of severability of limitations. For a complete discussion of the case, see Lynn \& Carpenter, supra note 50, at 38-44. 
striction on the duration of a directed accumulation for charity, although a court may terminate it. ${ }^{01}$

In 1956 Pennsylvania adopted by statute the common-law Rule Against Accumulations including the exception covering a directed accumulation for charity. ${ }^{62}$ In James' Estate, ${ }^{63}$ the testator directed a four-hundred year accumulation of a portion of the income of a charitable trust. The charitable beneficiary petitioned for leave to deviate from the administrative terms of the trust, asserting that the provision for accumulation was unreasonable and illegal. At issue was the proper construction of the legislative direction that the statutory provisions under which an accumulation of income is declared void shall not apply to an accumulation of income for charity. The orphans' court read the statute literally and held that it was without authority to pass on the reasonableness of the directed accumulation. ${ }^{64}$ On appeal the Pennsylvania Supreme Court reversed and remanded:

We may not view the statute as the mere utilization of words employed in an exclusively literal sense without regard to the social circumstances, charitable needs and public policy surrounding the legislation. So considered, its provisions require the application of a doctrine of reasonableness. ${ }^{65}$

Even New York, with its statutory substitute for the common-law Rule Against Perpetuities, has felt the tempo of the reform movement. One of the few attempts at comparatively systematic codification of property law was made in New York early in the nineteenth century. Although occasionally amended, those sections of the New York Revised Statutes of 1830 on the law of property have been a source of perplexity to the bench and bar for well over a century, and despite the reforms of 1958-1961, they will continue to cause trouble for years to come. ${ }^{66}$ Apparently, the complicated New York statutory scheme of 1830 contained a Rule Against Perpetuities that attempted to preserve alienability by invalidating certain kinds of future interests which either suspended the power of alienation or vested remotely. But

61 6 American Law of Property \$\$24.42, .65 (Casner ed. 1952); 5 Powell IIII 831-32; SIMES \& SMITH $\S \S 1465,1467$.

62 Pa. Stat. Ann. tit. 20, $\$ 301.6-7$ (Supp. 1963).

63414 Pa. 80, 199 A.2d 275 (1964).

64 Id. at 84,199 A.2d at 277 .

65 Id. at 85-86, $199 \mathrm{~A} .2 \mathrm{~d}$ at 277 .

66 For excellent studies of perpetuities statutes and related problems see NEW York LAw Revision Commission Leg. Doc. No. 65(H) (1936) and NEW YoRK LAw Revision Comanission Leg. Doc. No. 65(M) (1938) reprinted in 1950 by the Cormell Law Quarterly. For a comprehensive treatment of perpetuities in $\mathrm{New}$ York see 5 POWELI $\{\pi$ 791-807A. 
whatever the nature of the rule in New York, it is clear that the Revised Statutes did not dispel confusion. On the contrary the statutes created obstacles to the fulfillment of legitimate desires of settlors and testators. In particular the statutes (1) limited the permissible period for suspension of the power of alienation to two "lives in being"; (2) made no provision for a minority, except in a limited sense; (3) omitted any period in gross; and (4) made all trusts to collect and pay over rents and profits or income spendthrift trusts subject to the two-lives rule. ${ }^{67}$ Only by the process of tortured construction were the courts able to preserve many reasonable dispositions of property. Judicial efforts to give relief from the statutes were not without their price: in order to preserve, in form at least, the two-lives rule and its attendant intricacies, simplicity and predictability, were sacrificed. And even so, the desires of the ordinary settlor or testator could only be approximated. For example, a trust could not be limited solely upon a term of years, no matter how short. As a result, year after year, notwithstanding the fact that generations of draftsmen were warned repeatedly of the subtleties of the New York rules, there was a parade of cases requiring judicial surgery. Not every case could be judicially cured.

By a series of acts, New York has now moved from its two "lives in being" for measuring the permissible period for suspending the power of alienation to any reasonable number of lives in being at the creation of the interest and twenty-one years. ${ }^{\text {os }}$ Complementary legislation has made it clear that the validity of an interest created by the exercise of a power of appointment turns on the law in effect at the time of the exercise of the power, not at the time of its creation. ${ }^{69}$ The restriction on the creation of more than two successive legal life estates has been removed. ${ }^{70}$ Restrictions on the creation of remainders on terms of years have been removed. ${ }^{71}$

However, New York has not returned to the common-law rule. ${ }^{\text {t2 }}$ The traditional statutory language concerning the suspension of the power of alienation was retained. Nearly all income trusts are still spendthrift trusts automatically. ${ }^{73}$ But New York did enact a group

67 Pasley, The 1960 Anendments to the New York Statutes on Perpetuities and Powers of Appointment, 45 CORNELL L.Q. 679, 680 (1960); Sparks, Future Interests, in 1958 ANNUAL SURVEY AMERTCAN L. 577, 584. 1964).

68 N.Y. Pers. Prop. Law $\$ 11$; N.Y. Real Prop. Law $\$ 42$ (McKinney Supp.

69 N.Y. Laws 1964, ch. 864 (effective June 1, 1965) (repealing N.Y. REAL Prop. LAW \$179-b (McKinney Supp. 1964).

302 N.Y. Laws 1960 , ch. $449, \S 1$, at 1521 .

71 N.Y. Real Prop. LaW $\$ 50$ (McKinney Supp. 1964).

72 See Sparks, Future Interests, in 1960 Annual Survey Amarican L. 486, 493.

73 See Pasley, supra note 67, at 720 . 
of statutes designed to minimize the harsh effects of applying its perpetuities rule. These statutes are similar to those enacted in a number of states having the common-law rule and include rules of construction designed to meet the "unborn widow" and "administration contingency" ${ }^{74}$ problems, as well as a cy pres provision for reducing age contingencies to twenty-one where the perpetuities rule is violated. ${ }^{75}$

\section{The EngLish Reform}

Because the Rule Against Perpetuities is used in the United States primarily to police gift transactions for family purposes, ${ }^{76}$ the aspects of the English act of chief interest to the American lawyer are the adoption of a "wait and see" test for the validity of interests under the rule, ${ }^{77}$ the rejection of the "all-or-nothing" class-gift rule ${ }^{78}$ of Leake v. Robinson, ${ }^{79}$ and the particular attention given to the problems of fertility, sterility, adoption, and the like. ${ }^{80}$ The perpetuities reform movement in the United States did not include a re-examination of the common-law Rule Against Accumulations or the statutory rules on accumulation of income, and, therefore, a comparison of American provisions on accumulations with those of the English act is inappropriate. The newer versions of the rule in the United States do not single out powers of appointment for special attention, ${ }^{81}$ whereas the English act does. ${ }^{82}$ There are other provisions of the English reform statute which have no exact counterpart here. For example, as a part of its sweeping reform of the Rule Against Perpetuities in 1963, California established a sixty-year period in gross for testing the validity of contingent future interests under the rule. ${ }^{83}$ This is the longest period in gross provided for in the United States. Section 1 of the English act permits specification of a period in gross not to

74 N.Y. Pers. Prop. Law §§11-b(3), (4) ; N.Y. Real Prop. Law §§ 42-c(3), (4) (McKinney Supp. 1964).

75 N.Y. Pers. Prop. Law §11-a; N.Y. Real Prop. Law §42-b (McKinney Supp. 1964).

76 The best known exception to the generalization in the text is the application of the Rule Against Perpetuities to options in gross to purchase land. Under the orthodox rule, an option in gross is void if it is exercisable beyond the perpetuities period. 6 AMERICAN LAW of Property §24.56 (Casner ed. 1952); 5 Poweli $\int 771$ (2); Srmes \& SMrte $\$ 1244$. Simes and Smith say: "it may well be argued that the rule against perpetuities was designed primarily to restrict family settlements and not commercial transactions, and that an option to purchase land is nearly always a part of a commercial transaction." Id. $\S 1244$, at 159 .

77 Perpetuities and Accumulations Act, 1964, 13 Eliz. 2, c. 55, § 3.

78 Perpetuities and Accumulations Act, 1964, 13 Eliz. 2, c. 55, $\$$ 4(1), (4).

79 2 Mer. 363, 35 Eng. Rep. 979 (Ch. 1817).

80 Perpetuities and Accumulations Act, 1964, 13 Eliz. 2, c. 55, §2.

81 See Lynn, A Practical Guide to the Rule Against Perpetuities, 1964 Duke L.J. $207,242-45$.

82 Perpetuities and Accumulations Act, 1964, 13 Eliz. 2, c. 55, §7.

83 CAL. Crv. Code $\$ 715.6$ (Supp. 1964). 
exceed eighty years for perpetuities purposes. It is assumed that this provision is designed to discourage the use of royal-lives clauses for the purpose of measuring the perpetuities period. ${ }^{84}$ Under section $9(2)$ the life of options in gross to purchase land has been limited to twentyone years. In the United States an option in gross is void under the orthodox rule if it is exercisable beyond the perpetuities period. ${ }^{85}$ Problems raised by long-term options complying with the requirements of the rule have been largely ignored in this country. ${ }^{86}$

Section 12 of the statute puts possibilities of reverter and possibilities of resulting trust within the purview of the rule. ${ }^{87}$ In this country there are occasional statutes designed to handle problems raised by possibilities of reverter, rights of entry for condition broken, and contingent executory interests following limitations in fee, but the statutory language is not uniform and the techniques followed vary..$^{88}$ 627 (1964).

84 See Battersby, The Perpetnities and Accumulations Act, 1964, 108 Sor. J.

856 American Law of Property $\$ 24.56$ (Casner ed. 1952).

86 See ibid.

87 In England a right of entry for condition broken after a fee simple is subject to the common-law Rule Against Perpetuities. In re Trustees of Hollis' Hospital and Hague's Contract, [1899] 2 Ch. 540.

88 Mass. Gen. Laws ANN. ch. 184A, \& 3 (Supp. 1963) :

A fee simple determinable in land or a fee simple in land subject to a right of entry for condition broken shall become a fee simple absolute if the specified contingency does not occur within thirty years from the date when such fee simple determinable or such fee simple subject to a right of entry becomes possessory. If such contingency occurs within said thirty years the succeeding interest, which may be an interest in a person other than the person creating the interest or his heirs, shall become possessory or the right of entry exercisable notwithstanding the rule against perpetuities.

$A$, owning land in fee simple absolute, devises to $B$ and his heirs so long as the land is used for church purposes, then to $C$ and his heirs. If the use for church purposes ceases within thirty years after $A$ 's death, the contingent executory interest in $C$ is transformed into a fee simple absolute. $A$, owning land in fee simple absolute, devises to $B$ and his heirs, but if the land shall cease to be used for church purposes, then to $C$ and his heirs. The contingent executory interest in $C$ is void ab initio both at common law and under the Massachusetts statute.

In Kentucky the equivalence of the possibility of reverter, the right of entry for condition broken, and the contingent executory interest following a limitation in fee appears to be complete under the language of these statutes:

The estate known at common law as the fee simple determinable and the interest known as the possibility of reverter are abolished. Words which at common law would create a fee simple determinable shall be construed to create a fee simple subject to a right of entry for condition broken. In any case where a person would have a possibility of reverter at common law, he shall have a right of entry.

Ky. Rev. Stat. $\$ 381.218$ (1962).

A fee simple subject to a right of entry for condition broken shall become a fee simple absolute if the specified contingency does not occur within thirty years from the effective date of the instrument creating such fee simple subject to a right of entry. If such contingency occurs within said thirty years the right of entry, which may be created in a person other than the person creating the interest or his heirs, shall become exercisable notzeithstanding the rule against perpetulities.

Ky. Rev. Stat. $\$ 381.219$ (1962). (Emphasis added.) If $A$, owning land in fee simple absolute, grants to $B$ and his heirs, but if the land shall cease to be used 
A cy pres provision for reducing age contingencies is a feature of the English perpetuities reform act of $1964,{ }^{89}$ but it is not a novelty. A comparable provision was a part of the English Law of Property Act of 1925.90 Nevertheless, its inclusion raises questions regarding the order of priority between "wait and see" and cy pres. Suppose a devise to $A$ for life, remainder to such of the children of $A$ as attain the age of twenty-five. $A$ is capable of conceiving a child after the testator's death, and "children" is construed to mean "children of $A$ whenever born." Proper disposition of such a case under "wait and see" coupled with the English cy pres provision for reducing age contingencies proceeds on three principles: first, deferring reformation until it is clear that the gift to the children cannot vest within the perpetuities period as measured by actual events; second, reducing age contingencies only to the extent necessary to validate the gift; and third, reforming to prefer possible beneficiaries alive at the time of reformation unless unfairness results from excluding the successors in interest of those who could have qualified as beneficiaries of the gift as reformed, were they not already dead at the time of reformation. For example, suppose that in the case put $A$ dies survived by four children, two of whom $(B$ and $C$ ) are under four years of age (being one and two, respectively) and were unborn at the testator's death, and two of whom ( $D$ and $E$ ) are over four years of age (being five and six, respectively), and were likewise unborn at the testator's death. No child of $A$ alive at the testator's death or born thereafter had attained

for church purposes, then to $C$ and his heirs, $B$ in Kentucky has a fee simple subject to a right of entry in $C$. If the use for church purposes ceases within thirty years after delivery of the deed, the right of entry in $C$ is transformed into a fee simple absolute. If the use for church purposes continues beyond thirty years after delivery of the deed, the fee simple in $B$ becomes absolute.

In California the executory interest in $C$ is vested and exempt from the Rule Against Perpetuities because California enacted the following statute as a part of the perpetuities reform act of 1963: "An interest in real or personal property, legal or equitable, is vested if and when there is a person in being who could convey or there are persons in being, irrespective of the nature of their respective interests, who together could convey a fee simple title thereto." CAL. CIv. CoDE ANN. \$715.8 (Supp. 1964). The repeal of this statute has been urged. Comment, California Revises the Rule Against Perpetinties-Again, 16 Stan. L. Rev. 177, 190 (1963).

The suggested construction of the Kentucky statutes assumes that courts will read them as declarations of policy and will disregard technical distinctions raised by the language of the statutes. Professor Dukeminier does not read the statutes in the way I suggest. He says:

The fee simple subject to divestment by an executory limitation is not affected by [Ky. REv. STAT.] . . \$ $\$ 381.218$ or . . . \$381.219. It is not used to restrict the use of land and is not within the reasons for these sections. It remains subject to the common laze Rule against Perpetuities as modified by [Ky. Rev. Stat.] . . \$381.216.

Dukeminier, Kentucky Perpetuities Laze Restated and Reformed, 49 Ky. L.J. 3, 75 (1960). (Emphasis added.)

89 Perpetuities and Accumulations Act, 1964, 13 Eliz. 2, c. 55, §4(1). 90 Law of Property Act, 1925, 15 \& 16 Geo. 5, c. 20, § 163 (repealed). 
twenty-five at $A$ 's death. The validity of the gift to the children cannot be demonstrated at $A$ 's death, and determination of validity is deferred. Both $D$ and $E$ die before attaining twenty-five ( $B$ and $C$ being still alive). $B$ and $C$ cannot attain twenty-five within the perpetuities period, and the gift is then reformed to read "remainder to such of the children of $A$ as attain twenty-two." The successors in interest of any child of $A$ alive at the testator's death or born thereafter who had attained twenty-two before dying should share in the gift as reformed. ${ }^{91}$ Reformation assures validity under the rule, but it does not assure vesting. If no child of $A$ alive at the testator's death or born thereafter attains twenty-two, the gift to the children fails by its own terms. Because the sweeping American " 'wait and see' coupled with cy pres" versions of the rule are couched in language that is general rather than specific, pushing the outer limits of the perpetuities period as far as "wait and see" permits is permissible, but not required, here in the United States. ${ }^{92}$

91 There is a disadvantage to the solution of the problem posed by the hypothetical case in text. Had $D$ or $E$ attained twenty-two before dying, his successor in interest would take rather than $D$ or $E$ himself. Were the gift reformed at $A$ 's death, $D$ or $E$ could share personally under the circumstances suggested. Nevertheless, the justification for deferring reformation as long as possible can be demonstrated by the following variation on the facts of the hypothetical case posed in the text. Suppose that both $B$ and $C$ die one year after $A^{\prime}$ s death ( $D$ and $E$ being still alive). $D$ and $E$ will attain twenty-five, or not, within the perpetuities period, namely, $A^{\prime}$ s lifetime and twenty-one years. Therefore there is no reason to reform the gift.

92 American "wait and see" coupled with cy pres versions of the rule are less stringent in their requirements than is the English statute for several reasons.

First, American statutes are short and catholic in scope. Vermont's statute reads as follows :

Any interest in real or personal property which would violate the rule against perpetuities shall be reformed within the limits of that rule, to approximate most closely the intention of the creator of the interest. In determining whether an interest would violate said rule and in reforming an interest the period of perpetuities shall be measured by actual rather than possible events.

VT. Stat. AnN. tit. 27, $\$ 501$ (1959). Under the Vermont statute a court has more freedom to shape the law than has an English judge working within the confines of the new act. Because New Hampshire achieved its "wait and see" coupled with cy pres version of the rule by judicial decision, Merchants Nat'l Bank v. Curtis, 98 N.H. 225, 97 A.2d 207 (1953); Edgerly v. Barker, 66 N.H. 434, 31 Atl. 900 (1891), the development of perpetuities law there is relatively unrestricted.

Second, the choice of "lives in being" for purposes of measuring the perpetuities period tends to be left open in the United States. Even the Kentucky "wait and see" coupled with cy pres statute is less than explicit: "provided, however, the [perpetuities] period shall not be measured by any lives whose continuance does not have a causal relationship to the vesting or failure of the interest." KY. REv. STAT. \$381.216 (1962). By contrast, $\S 3(5)$ of the English act limits the measuring lives to the donor himself, beneficiaries of gifts, parents and grandparents of beneficiaries, and persons with interests on the failure or determination of which gifts are to take effect.

Third, the desire for simplicity may discourage pushing the outer limits of the perpetuities period as far as "wait and see" permits. Class gifts are commonplace, and the difficulties of applying rules regulating class gifts should be minimized. See Lynn, A Practical Guide to the Rule Against Perpetuities, 1964 Duke L.J. 207, 231 n.87, 237-39. 
The English act, like its American counterparts, does not state a precise rule for determining the priority of "wait and see" and cy pres. ${ }^{93}$ But deferring reformation as long as possible is consistent with the underlying justification for "wait and see," namely, carrying out the intention of the donor unless he violates the Rule Against Perpetuities in fact. Reformation complements "wait and see"; it does not displace it.

The limited cy pres provision of the new act is directed at the discredited "all-or-nothing" rule of Leake $v$. Robinson, ${ }^{94}$ under which a class gift stands or falls as a unit for perpetuities purposes. Under Leake the gift to an entire class is void if the interest of any member of the class might vest remotely. The class cannot be split to save gifts that taken by themselves are good. For example, suppose a devise to $A$ for life, then to $A$ 's children for their lives, remainder in fee to the grandchildren of $A$. If "grandchildren" is construed to mean "grandchildren of $A$ irrespective of when their parent or parents (a child or children of $A$ ) are born," the gift to grandchildren is bad in its entirety under the orthodox rule because a child might be born to $A$ after the testator's death, and the ultimate number of grandchildren sharing in the gift (and therefore the ultimate size of each share) might not be determinable until the death of a person unborn at the testator's death, namely, such afterborn child of $A$. Sections 4(3) and 4(4) of the English act permit splitting the class, if necessary, to save the gift. If a child born to $A$ after the testator's death is the survivor of $A$ 's children, the validity of the gift to grandchildren cannot be demonstrated under "wait and see" at the death of the survivor of $A$ 's children alive at the testator's death, because the afterborn child of $A$ might have a child beyond the perpetuities period. If a child is born to

93 The matter of priority between "wait and see" and cy pres caused disagreement within the English Law Reform Committee which reported on the Rule Against Perpetuities in 1956. A majority of the committee recommended applying the cy pres provision for reducing age contingencies first, the "wait and see" rule second, and the new class-splitting rule last. Law REForM Commitree, Fourth Report No. 18, at 14-15 (1956). Two members of the committee dissented from this view, including Dr. J. H. C. Morris, co-author of MorRIs \& LeACH, The Rule Against Perpetuities (2d ed. 1962). Three additional members concurred in their dissent. LAw ReForm CoMmittee, Fourth Report No. 18, at 34-35 (1956). The dissenting members stressed carrying out the testator's intention insofar as applicable rules permit: "If the testator gives property to 'the children of A at 25,' he presumably means what he says." Ibid. The Law Reform (Property, Perpetuities, and Succession) Act of 1962 of Western Australia explicitly provides for the priority of "wait and see" over cy pres, and the priority of cy pres over the class-splitting rule. Law Reform Act, 1962, 11 Eliz. 2, No. 83, § 11 (W. Austl.).

That the views of the dissenting members of the English Law Reform Committee ultimately prevailed is borne out by both the format and the language of the new statute. Subsections (1), (2), and (3) of $\S 3$ of the act operate "apart from . . . sections 4 and $5 \%$ (dealing with cy pres, class-splitting, and the unborn widow problem). Perpetuities and Accumulations Act, 1964, 13 Eliz. 2, c. 55, $\$ 3$.

842 Mer. 363, 35 Eng. Rep. 979 (Ch. 1817). 
the afterborn child of $A$ beyond the perpetuities period, the gift to grandchildren is bad under "wait and see" alone because the ultimate number of grandchildren sharing in the gift is not fixed within the perpetuities period. The class of grandchildren is split under the English act to exclude a grandchild born beyond the perpetuities period. The classsplitting feature of the English act has no counterpart in the reform legislation enacted in the United States. ${ }^{95}$ Indeed the language of the Pennsylvania perpetuities statute appears to require that the gift to grandchildren stand or fall as a unit. ${ }^{96}$

In sum the English perpetuities reform act of 1964 is more comprehensive than its American counterparts. It does not follow that it is more drastic. The cy pres feature of the act is confined to reducing age contingencies..$^{97}$ The class-splitting provision ${ }^{98}$ is a pioneer, but it applies only if "wait and see" and cy pres prove insufficient to validate a gift. California, with its sweeping cy pres version of the rule, ${ }^{99}$ and Kentucky, ${ }^{100}$ New Hampshire, ${ }^{101}$ and Vermont, ${ }^{102}$ with their combinations of "wait and see" and cy pres, permit validation of a much higher proportion of contingent future interests than does England.

Nevertheless, the adoption of "wait and see" in England is likely to have effect elsewhere. The English reform statute gives greater respectability to a version of the rule which has been subjected to con-

95 Nevertheless, it is conceivable that under cy pres versions of the rule, classsplitting will be resorted to in order to save gifts.

86 If the afterborn child of $A$ within the perpetuities period becomes incapable of conceiving a child, the language of PA. STAT. ANN. tit. 20, $\$ 301.4(\mathrm{~b})(1950)$, is no bar to validating the gift to the grandchildren of $A$ : "Upon the expiration of the [perpetuities period] ... as measured by actual . . events ... any interest in members of a class the membership of which is then subject to increase shall be void." If no child is born to the afterborn child of $A$ beyond the perpetuities period and the perpetuities question is raised after the death of the afterborn child, the gift to the grandchildren should be upheld in Pennsylvania. To invalidate the gift under such circumstances is to turn the actualities test of "wait and see" into the possibilities test of the orthodox rule, and there is no reason for doing so. If the perpetuities question is raised at a time beyond the perpetuities period but during the life of the afterborn child of $A$, then the gift to the grandchildren should be upheld if the afterborn child of $A$ is incapable of conceiving a child, and the perpetuities question should be deferred if the afterborn child of $A$ is capable of conceiving a child. In the latter case Brégy appears to say that the gift is bad. BRÉGX, INTESTATE, WIILS, AND Estates ACTS of 1947, at 5266, 5278 (1949). PA. Stat. ANN. tit. 20, $\$ 301.5$ (c) (1950), is relevant here because the afterborn child of $A$ takes if the gift to the grandchildren is bad, but it is not decisive.

97 Perpetuities and Accumulations Act, 1964, 13 Eliz. 2, c. 55, §§4(1)-(2).

98 Perpetuities and Accumulations Act, 1964, 13 Eliz. 2, c. 55, $\$ 4(4)$.

99 CAL. Civ. Code $\$ 715.5$ (Supp. 1964).

$100 \mathrm{Ky}$. REv. STat. \$ 381.216 (1962).

101 Merchants Nat'l Bank v. Curtis, 98 N.H. 225, 97 A.2d 207 (1953) ; Edgerly

v. Barker, 66 N.H. 434, 31 At1. 900 (1891).

102 VT. Stat. ANn. tit. 27, § 501 (1959). 
tinual attack, some of it relatively recent. ${ }^{103}$ Reformation of the rule in England increases the likelihood of re-examination of the rule in jurisdictions where the tradition of English law is even stronger than it is with us. ${ }^{104}$ Furthermore, and most important, reformation in England gives impetus to the accelerating perpetuities reform movement of the last two decades.

\section{CONCLUSION}

It has been said that the chief objectives of the Rule Against Perpetuities in orthodox form are to curtail dead-hand control of wealth and to facilitate the marketability of property. ${ }^{105}$ Insofar as the rule was intended to preclude the creation of family dynasties, it has proved a signal failure. As a device to facilitate marketability, it is exceptionally awkward. But it does help to strike a balance between the wishes of the dead and the desires of the living with respect to the use of wealth. ${ }^{108}$ Neither perfect in conception nor clear in application, the rule has withstood repeated assaults. Irrespective of the form that it takes, bench and bar can make the rule work sensibly if they wish to do so. In this connection lawyers working under the orthodox rule have been given an assist by those who have educated the bar to the desirability of reform, for in the long run applying the rule properly turns on using available information intelligently, rather than following discredited precedent blindly.

It does not follow that there is no choice at all among the competing versions of the rule. "Wait and see" and cy pres, or a combination of them, are versions less strict than the orthodox rule, and that is true even where the orthodox rule has been relaxed by statutes designed to meet particular situations that have brought the rule into disrepute. Because perpetuities law is peculiarly lawyers' law, the bar in a jurisdiction should select its version of the rule and stick with it. The Rule Against Perpetuities is not sacrosanct. On the other hand, it is not the Internal Revenue Code. It ought not to be treated as if it were.

103 E.g., Jones, Measuring Lives Under the Pennsylvania Statutory Rule Against Perpetuities, 109 U. PA. L. REv. 54 (1960).

104 Western Australia enacted its version of the English perpetuities reform legislation in 1962. Law Reform (Property, Perpetuities, and Succession) Act, 1962, 11 Eliz. 2, No. 83 (W. Austl.).

105 Gulliver, Cases on Future Interests 76 (1959).

106 Simes, Public Policy and the Dead Hand 55-63 (1955). 